\title{
COMENTÁRIO FILOLÓGICO E CRÍTICA MATERIALISTA
}

Jeanne Marie Gagnebin ${ }^{1}$

Aos "meninos" de Belém, que me obrigaram a ler junto Benjamin e Nietzsche: Ernani Chaves, Henry Burnett e Márcio Benchimol. E em homenagem ao mestre de Belém, desaparecido: Benedito Nunes.

RESUMO: A partir do ensaio (1922) de Walter Benjamin sobre as Afinidades Eletivas de Goethe, o artigo tenta mostrar como Benjamin, desde esse ensaio de juventude até seu último texto, as teses "Sobre o conceito de história" (1940), defende uma noção de filologia crítica, capaz de evidenciar no detalhe material a distância histórica que separa a obra, em sua concretude histórica, do momento histórico do intérprete ou historiador. Somente o reconhecimento desse distanciamento permite não cair nas armadilhas da Einfüblung (identificação afetiva, empatia) hermenêutica e possibilita elaborar um posicionamento histórico e crítico.

PALAVRAS-CHAVE: Walter Benjamin. Crítica. Filologia. Distância histórica.

O título acima proposto alude a dois tipos de figuras que habitam nossas faculdades de ciências humanas, literatura e filosofia: os críticos engajados, geralmente de origem marxista, e os cientistas dedicados e pacientes, curvados sobre textos na língua original. Os primeiros, os críticos, julgam geralmente os segundos aborrecidos e pouco relevantes socialmente, mesmo que não ousem

\footnotetext{
1 Jeanne Marie Gagnebin nasceu em Lausanne (Suíça), em 1949. Estudou Filosofia, Literatura alemã e Grego antigo na Universidade de Genebra. Concluiu o Doutorado em Filosofia, na Universidade de Heidelberg (Alemanha), em 1977. Vive e leciona no Brasil desde 1978. Fez vários estágios de Pós-Doutorado em Konstanz, Berlin e Paris. Atualmente, é professora titular de filosofia na PUC/ SP e livre-docente em Teoria Literária pela UNICAMP. Principais publicações: Zur Geschichtsphilosophie Walter Benjamins, Erlangen, 1978; Walter Benjamin. Os Cacos da História, São Paulo, 1982; Histoire et narration chez Walter Benjamin, Paris, 1994 (trad. br. História e Narração em Walter Benjamin, São Paulo, 1994; trad. alemã Geschichte und Erzählung bei Walter Benjamin, Würzburg, 2001); Sete Aulas sobre Memória, Linguagem e História, Rio de Janeiro, 1997; Lembrar. Escrever. Esquecer, São Paulo, 2006.
} 
contestar sua seriedade; e os filólogos consideram os primeiros dogmáticos e sem importância para a verdadeira pesquisa acadêmica, mesmo reconhecendo sua eventual coragem. Às vezes, a discrepância aparece de maneira pouco nuançada no debate jornalístico, como foi recentemente o caso da discussão para nomeação de um novo presidente da Casa Rui Barbosa, no Rio de Janeiro $^{2}$. Dois tipos de temporalidade se perfilam atrás dessa dicotomia: à paciência e à lentidão da filologia, que também seriam indício do estatuto privilegiado do pesquisador alheio ao combate pela vida, se opõe a rapidez da crítica conjuntural, a urgência exigida pela atualidade do momento.

Neste texto, gostaria de refletir sobre tais dicotomias, relativizando e nuançando essas oposições, sem pretender chegar a uma conciliação, mas propondo, na esteira de Walter Benjamin e, igualmente, de Nietzsche, a seguinte hipótese que também é uma aposta metodológica na filologia e na crítica: a atitude filológica autêntica se demora, antes de mais nada, na historicidade da linguagem, oferecendo dessa maneira uma porta de entrada privilegiada para uma crítica histórica e mesmo materialista, quando se leva a sério a materialidade das palavras. Dito em termos temporais: paciência e atenção poderiam servir não de pretextos, para se opor à necessidade de intervenção na urgência da situação, mas, pelo contrário, configurar um exercício de precisão que permite reconhecer o momento oportuno da ação.

Esse confronto entre filologia e crítica marca desde cedo as discussões e mesmo querelas que envolvem Walter Benjamin e seus diversos amigos marxistas, ainda que sejam eles pessoas tão diferentes, como Adorno e Brecht (que não se suportavam). Asja Lacis, a bela "comunista letã", como diz Scholem, era um membro convicto do Partido Comunista e uma diretora ativa de teatro infantil e proletário, quando conheceu Benjamin, em 1924, em Capri. Atração e conflito parecem ter sido recíprocos. Asja Lacis nos deixou uma descrição dessas primeiras discussões que é muito esclarecedora, tanto em sua seu entusiasmo militante, que beira a ingenuidade, quanto na tenacidade metodológica de Benjamin, mesmo quando não consegue se defender ideologicamente. Escreve Asja:

Falava muito sobre Goethe, com especial entusiasmo sobre As Afinidades Eletivas. Achava que essa obra fosse muito moderna na sua psicologia e

\footnotetext{
${ }^{2}$ Ver artigo sobre a eventual nomeação do sociólogo Eder Sader para presidência da Casa Rui Barbosa,
} no Caderno "Ilustríssima" da Folha de S. Paulo, do domingo, 27 de fevereiro de 2011. 
problemática e disse que estava trabalhando num ensaio sobre as Afinidades Eletivas ${ }^{3}$. Ele estava mergulhado no trabalho A Origem do Drama Barroco Alemão. Quando me explicou que se tratava de uma análise da tragédia alemã do século XVII; que essa literatura só era conhecida por alguns raros especialistas e que essas tragédias jamais haviam sido encenadas, eu fiz uma careta: para que se ocupar de literatura morta? Ele se calou por um momento e depois disse: "Primeiramente, eu introduzo uma nova terminologia na ciência, na estética. No que diz respeito ao drama moderno, se usam as palavras 'tragédia, drama barroco's indiferentemente, somente como palavras. Eu mostro a diferença de princípio entre tragédia e drama barroco. Os dramas do Barroco exprimem desespero e desprezo pelo mundo - são, realmente, jogos tristes" ${ }^{\prime 5}$. [...]

"Em segundo lugar", disse, "esse estudo não consiste numa simples pesquisa acadêmica, mas liga-se de maneira imediata a problemas muito atuais da literatura contemporânea. Ele enfatizou expressamente que caracterizava no seu trabalho a dramática do Barroco como uma aparição análoga ao Expressionismo na busca de uma linguagem formal ${ }^{6}$. Por essa razão", disse, "tratei tão detalhadamente a problemática artística da alegoria, dos emblemas e do ritual. [...]

$\mathrm{Na}$ época suas respostas não me satisfizeram. Perguntei-lhe se também via analogias entre a visão do mundo dos dramaturgos do barroco e a dos expressionistas, e quais interesses de classe elas exprimiam. Ele respondeu de maneira vaga, acrescentando em seguida que estava lendo Lukács e apenas começava a se interessar por uma estética materialista. Nessa ocasião, em Capri, eu não compreendi bem a conexão entre alegoria e poética moderna. Retrospectivamente, entendo agora com que acuidade Benjamin penetrou nos problemas modernos da forma. ${ }^{7}$

Com candura, Asja conta de mais uma incompreensão sua em relação ao interesse que Benjamin tinha pelos sonhos, os próprios e os dos outros, como se o sonho fosse, assim afirma ele, no ensaio "Experiência e Pobreza", um tipo de "ressarcimento" pelas fadigas e dificuldades do dia - o que ela agora

\footnotetext{
${ }^{3}$ Parece haver aqui uma imprecisão nas lembranças de Asja Lacis, pois o ensaio sobre As Afinidades eletivas de Benjamin foi redigido em 1922, sendo publicado, isso sim, em duas partes, na revista dirigida por Hugo von Hofmannsthal, Neue Deutsche Beiträge, em 1924 e 25. A esse respeito, ver o verbete de Burkhardt Lindner sobre o ensaio de Benjamin, no volume Benjamin-Handbuch, org. por Burkhardt Lindner (Stuttgart: Metzler Verlag, 2006, p. 472 e seguintes).

${ }^{4}$ Em alemão: Tragödie, Trauerspiel.

${ }^{5}$ Em alemão: traurige Spiele.

${ }^{6}$ Em alemão: Formsprache.

${ }^{7}$ LACIS, Asja. Revolutionär im Beruf. München: Rogner \& Bernhard 1976, p. 47-48.
} 
entende $^{8}$. As incompreensões de Asja iluminam os aspectos redutores de uma certa estética marxista (aspectos que Benjamin deveria, mais tarde, condenar), que somente aceita a relevância de uma obra, quando consegue estabelecer claramente e racionalmente uma dupla relação: a do autor com a luta de classes e a da obra com a atualidade, entendida como uma contemporaneidade imediata. A essas exigências de funcionabilidade direta, Benjamin resiste, insistindo na necessidade do desvio pela diferenciação linguística e conceitual, procurando na explicitação da diferença e do detalhe uma historicidade própria que pode ser - ou não - colocada em relação com o presente, mas que sempre especifica um momento singular do passado. Assim, a literatura "morta", como a chama Asja, se transforma num manancial de singularidades que podem esclarecer a "viva", justamente porque dela difere; mas esse esclarecimento recíproco tem por condição que se cumpra um movimento complexo: reconhecer a distância histórica que separa o passado do presente, em vez de buscar primeiro por supostas semelhanças, e reconhecer que essa distância também é apreendida de várias maneiras, segundo o modo nada inocente de sua transmissão. Distância e transmissão: esses dois conceitos percorrem a obra inteira de Benjamin, desde sua tese de doutorado Sobre o Conceito de Crítica de Arte no Romantismo Alemão" até as teses "Sobre o conceito de história", seu último texto, escrito em 1940.

Nesse contexto, o ensaio de Benjamin sobre As Afinidades eletivas de Goethe, ao qual aludem as conversas com Asja Lacis, é, com efeito, um marco decisivo. Trata-se de um texto denso e difícil, com pressupostos profundamente metafísicos, que fornece um elo privilegiado de ligação entre o doutorado sobre o conceito de crítica no Romantismo alemão, ainda marcado pelo estilo da tese acadêmica, e o livro muito mais ousado e pessoal sobre o drama barroco ${ }^{10}$. No ensaio de 1922, Benjamin critica a interpretação hagiográfica de Goethe, presente na biografia de Friedrich Gundolf (Goethe, 1916), uma interpretação que realça a figuração olímpica do poeta e, por ricochete, a solene reconfiguração classicista da República de Weimar. Aponta igualmente para o esforço do próprio Goethe, em Weimar, em construir essa autoimagem em oposição à sua juventude conturbada e entusiasta da época

${ }^{8}$ LACIS, Asja, op. cit., p. 54. Uso a tradução feita no meu livrinho de 1982 (Ed. Brasiliense), Walter Benjamin. Os cacos da história.

${ }^{9}$ Traduzido no Brasil por Márcio Seligmann-Silva na Editora "Iluminuras", São Paulo, 1993.

${ }^{10}$ Retomo aqui algumas hipóteses desenvolvidas na resenha que escrevi a respeito da tradução brasileira desse ensaio, no Jornal de resenhas, Discurso Editorial, USP, número 9, março de 2010. 
do Sturm und Drang (literalmente: "tempestade e ímpeto", um movimento literário do fim dos anos 1760). A escrita das Afinidades Eletivas marcaria o início do período da velhice do escritor (então com sessenta anos) e o ápice desse processo de construção clássica da qual a frágil República de Weimar quis se tornar herdeira. A grandeza do romance consiste, segundo a interpretação de Benjamin, no fracasso dessa tentativa: Goethe não conseguiria, justamente porque é um grande escritor, atento às contradições, mesmo não explicitadas, que o atravessam como a seu tempo, forjar uma imagem paradigmática da instituição do casamento e da Aufklärung civilizadora, que leva os personagens a edificar monumentos e jardins.

Para nosso propósito aqui, é suficiente um breve resumo da obra de Goethe: o livro conta o desmoronamento do casamento de Carlota e Eduardo, dois membros da aristocracia culta, tolerante e delicada, figuras de uma nobreza idealizada pelo escritor. A união se desfaz, apesar do amor primevo e da recíproca estima, pela introdução de duas personagens, que são também dois amigos do casal, convidados a morar com eles, por razões diversas, durante algum tempo.

Primeiro recebido com desconfiança, porque a figura da Otília, a bela jovem pela qual Eduardo se apaixona, não é negativa, mas, pelo contrário, uma sublime encarnação da beleza e da melancolia, o romance foi depois interpretado de maneira conivente com o crescente culto à olímpica figura do escritor como a afirmação da necessidade do casamento e condenação do adultério. Benjamin destrói consequentemente essa monumentalização. Relendo o romance, descobrimos, então, outra beleza, muito mais contraditória do que a do estilo clássico e da descrição da paixão (infeliz, naturalmente). A saber, dentro da própria trama, as dúvidas que perpassam a construção da temática explícita: gostar-se-ia de acreditar no casamento harmonioso entre Eduardo e Carlota, mas ele desmorona por forças "naturais" (a metáfora do título provém da química) que colocam em questão uma ética da decisão consciente. Ademais, o personagem que mais defende o casamento como instituição, Mittler, é um ex-pastor insuportavelmente tagarelo e trivial. Quanto a Otília, encarnação da beleza, ela é incapaz de ir além de uma passividade sofredora, acaba por matar (involuntariamente) o filho de Eduardo e de Carlota e por se deixar morrer a si mesma. Sua morte, interpretada como martírio de uma santa pelo povo, é também evocada como ápice perigoso de manifestações supersticiosas e mágicas. 
Goethe nutria uma admiração entusiasta pela Natureza, por suas leis e perfeições, em oposição à sua clara desconfiança em relação à História. No entanto, esse romance mostra com uma lucidez impressionante, à revelia das convicções do próprio escritor, como desmoronam juntos os edifícios naturais (o casal transforma sua propriedade num belíssimo parque) e culturais: a construção do jardim e da casa e a desconstrução do casamento progridem juntas. A maior beleza do romance consiste, pois, nessa luta interna à própria escrita da obra, entre uma vontade de construção de um modelo clássico de harmonia e, mesmo que entre as linhas, a confissão, simultaneamente corajosa e desolada, de sua impossibilidade. Poder-se-ia adiantar um paralelo profético com a infeliz reapropriação desse pseudoclassicismo pelos ideólogos da República de Weimar que, sob o manto da civilização da Aufklärung, deverá também sucumbir às forças do Mito, uma categoria-chave no ensaio de Benjamin.

Contra a construção dessa tradição clássica e harmonizante, Benjamin estabelece, nas primeiras páginas do ensaio, alguns princípios hermenêuticos - no sentido amplo de interpretação - muito rigorosos. Vale a pena citar este longo parágrafo metodológico:

A literatura atual sobre obras literárias (Dichtungen) dá a impressão que o cuidado com o detalhe (Ausfïbrlichkeit) em tais estudos deve-se mais a um interesse filológico do que crítico. É por isso que o estudo que segue, também uma exposição (Darlegung) detalhada das Afinidades Eletivas, poderia facilmente enganar sobre a intenção com que é apresentado. Poderia parecer um comentário; ele se pretende, contudo, crítica. A crítica busca o teor de verdade (Wabrheitsgehalt) de uma obra de arte, o comentário, seu teor "coisal"/de coisa (Sachgehalt). A relação dos dois determina esta lei fundamental da escrita literária: mais o teor de verdade de uma obra é significativo, mais o seu laço (gebunden) com o teor coisal é imperceptível e interior. Se, portanto, as obras que se revelam como duradouras são precisamente aquelas cujo teor de verdade está mais profundamente imerso no seu teor coisal, por sua vez os materiais de realidade histórica (Realien) da obra aparecem, para quem a considera no curso desta duração, de maneira tanto mais clara, quanto mais eles tendem a morrer no mundo. Com isso, teor de coisa e teor de verdade, unidos em seu modo de aparecer nos primeiros tempos (Frühzeit) da obra, aparecem, com seu perdurar, disjuntos, porque o último se mantém oculto sempre da mesma maneira, quando o primeiro vem à luz. Assim, a interpretação dos elementos que sobressaem e causam estranheza (des Befremdenden), quer dizer do teor de coisa, torna-se cada vez mais a condição preliminar da atividade crítica posterior. Pode-se comparar o crítico com o paleógrafo diante de um pergaminho, cujo texto, empalidecido, está recoberto pelos 


\begin{abstract}
traços de uma escrita mais vigorosa, que a ele se refere. Assim como o paleógrafo deveria começar pela leitura desta última escrita, da mesma maneira o crítico deve começar pelo comentário. E, de repente, surge um critério inapreciável para seu juízo: é somente então que ele pode colocar a questão crítica fundamental, a saber, se a aparência (Schein) do teor de verdade se deve ao teor de coisa ou se a vida do teor de coisa, ao teor de verdade. Pois na medida em que se dissociam na obra, decidem de sua imortalidade. Nesse sentido a história das obras prepara sua crítica e, por conseguinte a distância histórica aumenta sua força/violência/poder (Gewalt). Recorrendo a uma comparação poderia considerar-se a obra no seu crescimento (das wachsende Werk) como um monte de lenha em chamas diante do qual o comentador se postaria como um químico, e o químico, como um alquimista. Enquanto que para o primeiro a madeira e a cinza são os únicos objetos de sua análise, para o segundo somente a chama conserva um enigma (Rätsel): o do vivente (des Lebendigen). Assim, o crítico pergunta pela verdade, cuja chama viva continua a queimar sobre as pesadas achas do que foi (des Gewesenen) e a leve cinza do que foi vivenciado (des Erlebten). ${ }^{11}$
\end{abstract}

Esse parágrafo famoso marca a passagem de uma concepção romântica da crítica de arte, tal qual Benjamin a elucidou no seu doutorado, para uma concepção mais radicalmente histórica e temporal que deveria ser sua, desde o livro sobre o drama barroco, até suas últimas reflexões mais "materialistas". Com efeito, se Benjamin retoma a concepção do Romantismo de Iena segundo a qual a obra continua a crescer (wachsen), em sua vida ulterior, através da suas traduções e críticas, portanto, que a história de uma obra engloba a de sua recepscão, diríamos hoje, essas metáforas naturais são atravessadas pela afirmação da força, do poder, sim da violência (Gewalt) da distância histórica. A palavra "Gewalt", que deverá voltar no título do ensaio Zur Kritike der Gewalt ("Para uma crítica da violência”), se afasta do campo da Natureza e da problemática da dynamis e da energeia, assinalando um campo de forças históricas em luta, o que os textos da época "materialista" vão aprofundar. Ao mesmo tempo, o domínio da vida não é mais a exuberância do "vivido" (des Erlebten), mas reúne,

\footnotetext{
${ }^{11}$ BENJAMIN, Walter. As afinidades eletivas de Goethe, ensaio de 1922, Gesammelte Scbriften, I-1. Trad. de J. M. Gabnebin, com empréstimos à tradução de Mônica Krausz Bornebusch. Frankfurt/Main: Suhrkamp, 1974, p. 125/126, Ensaios reunidos: Escritos sobre Goethe. São Paulo: Ed. 34, 2009, p. 1114. Remeto a meu artigo A propósito do conceito de crítica em W. Benjamin. Revista Discurso, USP, número 13, 1983.
} 
inseparavelmente, destruição e (re)construção, a presença da morte e o enigma do vivo (das Lebendige), como o reflete a metáfora final do fogo e da chama ${ }^{12}$.

Dito de maneira mais precisa: a distância histórica não é simplesmente um intervalo de tempo sempre maior entre o tempo de produção da obra, seu primeiro período de recepção e os períodos posteriores, entre as épocas que os Românticos de Iena chamam de Frühreeite de Spätz̧eit, um modelo que implica o paradigma organicista de crescimento, amadurecimento e florescimento - mas que não parece, estranhamente, desembocar na morte. A distância histórica é a configuração da inelutabilidade do caráter passado (vergangen), daquilo que foi (das Gewesene): o passado morreu, mesmo que continue a "passar" no presente. Por isso, o trabalho do crítico não é primeiramente um revitalizar do passado, mas o reconhecimento das dimensões perecíveis da obra, dimensões de Vergänglichkeit, do caráter passageiro e efêmero das criações humanas históricas. "Crítica é mortificação das obras", afirmará Benjamin, no capítulo sobre a alegoria da Origem do Drama Barroco Alemão e explicita: "Mortificação das obras: por conseqüência, não - romanticamente - um despertar da consciência nas que estão vivas, mas uma instalação do saber nas que estão mortas. ${ }^{" 13}$ Em decorrência, conclui esse parágrafo denso do mesmo capítulo, as obras somente podem ser "salvas" pela crítica, quando a obra se transformou em ruína.

É essa discussão sobre vida e morte das obras que dá à distinção entre "comentário" filológico e "crítica" filosófica sua importância decisiva. A grande tentação da crítica literária e filosófica, segundo Benjamin, consiste em querer salvar uma verdade sempre viva nas obras do passado, um teor de verdade (Wabrheitsgehalt) desde já pressuposto, poupando-se o exercício, muitas vezes demorado e mesmo ingrato, do comentário que analisa o Sachgehalt, o teor de coisa ou o teor materia $1^{14}$. Ora, a verdade assume na obra uma figuração histórica e linguística (sprachlich) que é condição de sua exposição (Darstellung) e de sua nomeação; ela somente pode ser apreendida nesses elementos temporais e transitórios que são língua e história, mesmo

\footnotetext{
${ }^{12}$ Valeria a pena mapear essas metáforas da chama, do fogo, do incêndio, na obra de Benjamin, elementos que destroem, queimam, purificam, iluminam e dão calor.

${ }^{13}$ BENJAMIN, Walter. GW. I-1, p. 357, tradução ligeiramente modificada de S. P. Rouanet, A Origem do Drama Barroco Alemão. São Paulo: Brasiliense, p. 203/204.

${ }^{14}$ A tradução por "teor factual”, tanto em Rouanet (idem, p. 204) como na tradução do ensaio sobre as Afinidades Eletivas, por Mônica Krausz Bornebusch (op. cit. p. 12), parece-me aludir a uma dimensão de fatualidade totalmente ausente no pensamento de Benjamin.
} 
que, para Benjamin, a dimensão da verdade sempre remeta a algo de atemporal - reconhecível somente no tempo. Essa imbricação cerrada entre verdade e história (em particular, palavras históricas que se transformam e mudam de sentido), impede a descrição da obra em termos de forma e de conteúdo (FormInhalt), como se houvesse uma verdade eterna que assume formas variáveis e indiferentes a ela. Por isso, na esteira de Hegel e de Goethe ${ }^{15}$, Benjamin usa a palavra Gehalt, teor, e não conteúdo (Inhalt), um termo também adotado depois por Adorno. Somente o reconhecimento e a análise demorada do Sachgehalt, isto é, daquilo que pertence à especificidade do passado, de elementos que não compreendemos mais, mas que nos são estranhos - fremd -, que são os indícios da historicidade transitória tanto do passado da obra quanto da leitura do presente, somente tal análise filológica permite não cair nas armadilhas de uma interpretação acrítica. Geralmente, a interpretação se resume a uma projeção retrospectiva do presente sobre o passado, a uma confirmação das certezas do presente pelo apelo a uma pretensa autoridade do passado, da tradição (e ali vemos o interesse na construção de figuras ditas clássicas, como a de Goethe, para o intérprete presente poder dela se proclamar herdeiro).

O ensaio de 1922 sobre As Afinidades Eletivas prefigura a crítica de Benjamin, nas teses "Sobre o conceito de história", de 1940, ao conceito de Einfüblung ( identificação afetiva, empatia) do historicismo. Pretender alcançar o verdadeiro sem se deter no estranhamento da distância histórica é uma estratégia pseudocrítica que, sob o manto do respeito pelo passado, no fundo serve à manutenção das convicções do presente, porque evita o aprofundamento do caráter histórico e, portanto, transitório, de ambos: tanto do passado, às vezes tão estranho para nós, quanto do presente, que poderia - e deveria - se tornar menos familiar.

O comentário filológico será sempre para Benjamin a condição prévia da crítica. Se esta última não se apoiar no primeiro, mas sair sem preâmbulos em busca da "verdade", periga fracassar na idealização da "grande tradição" e, ao mesmo tempo, na afirmação do status quo, ou, pelo contrário, numa

\footnotetext{
${ }^{15} \mathrm{O}$ tradutor para o francês de Benjamin (Oeuvres I, folio Essais, 2000, p. 91, nota 2), Pierre Rusch, remete à seguinte passagem de Goethe, que meu colega Marcus Mazzari teve a gentileza de localizar: "Streit zwischen Form und Formlosem. Vorzug dem formlosen Gehalt vor der leeren Form. Gehalt bringt die Form mit. Form ist nie ohne Gehalt. Diese Widersprüche statt sie zu vereinigen disparater zu machen. Helles kaltes wissensch. Streben Wagner. Dumpfes warmes wissensch. Streben Scbüler. Lebens Thaten Wesen. Lebens Genuß der Person von aussen gesehn." (GOETHE, Weimarer Ausgabe, vol. XIV, p. 287, destaque meu). Trata-se de um paraplipomenon à cena "Quarto de trabalho II", no "Fausto P", segundo Mazzari.
} 
denúncia materialista vazia, não amparada numa análise pormenorizada do "material" histórico que possa ajudar a vislumbrar linhas de resistência possível. A defesa da filologia acontece, portanto, em Benjamin em duas frentes: contra a Literaturwissenschaft (ciência da literatura) dominante e suas construções monumentais ${ }^{16}$; mas também, como Asja Lacis já o suspeitava, contra uma certa crítica materialista militante, que busca separar o joio (aquilo que fortalece o domínio da burguesia) do trigo (o que trabalha a favor do proletariado e da revolução), e vê nessa separação o critério de verdade das obras de arte. Quando Adorno (que não incorre nessa posição simplista!) lhe pede uma posição teórica mais abrangente e dialética, "através do processo global", como enfatiza, sobre Baudelaire, em vez de se perder em "conteúdos pragmáticos da poesia de Baudelaire" e "traços vizinhos da história social"17, uma exigência teórica compreensível, mesmo que discutível, Benjamin não responde diretamente. Em vez disso, como se ainda não fosse o momento da elaboração crítica e teórica cobrada por Adorno, ele apela para a "atitude filológica" e cita, nessa discussão sobre paradigmas de crítica materialista, as diferenciações elaboradas no ensaio de juventude:

\begin{abstract}
Se você pensar retrospectivamente em outros trabalhos meus, você verá que a crítica da atitude filológica é uma antiga preocupação minha - e profundamente idêntica com a crítica do mito. Ela provoca, a cada vez, a operação filológica mesma. Para dizê-lo na linguagem das Afinidades Eletivas $^{18}$, ela visa o destaque dos teores materiais nos quais o teor de verdade é historicamente folheado. ${ }^{19}$
\end{abstract}

\footnotetext{
${ }^{16}$ A esse respeito, ver o pequeno texto de 1931, Literaturwissenschaft und Literaturgeschichte, GW III, p.283 e seguintes.

${ }^{17} \mathrm{Na}$ carta bastante aniquiladora de 10 de novembro de 1938 , sobre a primeira versão do livro sobre Baudelaire, intitulada A Paris do Segundo Império em Baudelaire (in: ADORNO, T.; BENJAMIN, W. Briefwechsel. Frankfurt/Main: Suhrkamp, 1994, p. 367).

${ }^{18}$ Adorno conhecia e apreciava muito o ensaio de 1922 sobre As Afinidades Eletivas. Essa recorrência a escritos anteriores, menos "materialistas" e muito admirados por Adorno, é um gesto frequente na Correspondência tardia por parte de Benjamin, quando tenta se defender contra as acusações de insuficiência teórica, em particular contra as suspeitas de sofrer em demasia a influência de Brecht, por parte de Adorno (e, atrás dele, de Horkheimer, isto é, do chefe do Instituto de Pesquisa Social que, não esqueçamos, lhe concedia uma bolsa!).

19 "Wenn Sie an andere meiner Arbeiten zurückdenken, so werden Sie finden, dass die Kritik an der Haltung der Philologen bei mir ein altes Anliegen - und zuinnerst identisch mit der am Mythos - ist. Sie provoziert jeweils die philologische Leistung selbst. Sie dringt, um in der Sprache der Wablverwandschaften zu reden, auf die Herstellungr der Sachgehalte, in denen der Wahreheitsgehalt historisch entblättert wird." (ADORNO, T. BENJAMIN, W. op. cit. p. 381, tradução minha. Retomo aqui algumas considerações expostas num artigo em francês, Philologie et Actualité (in: Topographies du souvenir. Le livre des passages de Walter Benjamin, organizado por Bernd Witte Paris: Presses Sorbonne Nouvelle, 2007).
} 
Porque o comentário filológico se atém à espessura contingente e histórica das "coisas", sempre incorre no risco, denunciado por Adorno, de se reduzir a uma mera "exposição admirada da facticidade"20, próxima do positivismo, o que Benjamin reconhece quando fala de uma espécie de encanto "mágico" exercido pela materialidade analisada sobre o pesquisador. Ele, no entanto, prefere assumir esse risco para não cair na armadilha inversa, a saber, a elaboração de uma ampla teoria dialética (ou não) que permite reencontrar no passado aquilo que o pesquisador do presente quer tanto nele descobrir. Ressoam nesse trecho da Correspondência várias polêmicas da teoria da cultura desenvolvida por teóricos marxistas da época como Lukács, mas também Ernst Bloch, a respeito dos bons usos das obras do passado cultural para as vanguardas de esquerda ${ }^{21}$. Benjamin se detém muito mais na reafirmação da disciplina filológica como pressuposto imprescindível para uma crítica histórica. Essa estreita relação entre filologia e bistória crítica se inscreve na linhagem do jovem Nietzsche, outro filólogo impenitente e polêmico, que Benjamin conhecia muito bem.

Cabe aqui um breve parêntese sobre a concepção nietzschiana da filologia ${ }^{22}$. Depois da publicação do Nascimento da Tragédia (1872) e da polêmica por ela provocada, em particular por parte de Willamowitz, Nietzsche precisa melhor sua crítica da prática vigente desta disciplina acadêmica chamada de "filologia", tal como ele mesmo a ensina na Universidade da Basileia.Vários dos fragmentos póstumos o testemunham. Três linhas de reflexão principal se destacam: a prática filológica em vigor, sustenta Nietzsche, é inseparável da defesa de sua influência e de sua autoridade pelos professores de filologia, defesa de um privilégio corporativista ligado a uma estrutura autoritária de ensino (o jovem Benjamin da Jugendbewegung não devia ficar insensível a esses acentos de crítico e de reformador do ensino, no pensamento de Nietzsche ${ }^{23}$ ). A imagem de uma Antiguidade dita clássica, imutável e eterna, não é estranha

${ }^{20}$ ADORNO, T; BENJAMIN, W. Briefwechsel, op. cit. p. 368.

${ }^{21}$ Tomo a liberdade de remeter a meu artigo sobre essa questão da "herança" (Erbetheorie) e da crítica radical de Benjamin a seus pressupostos historiográficos, no volume Pensamento alemão no século XX, org. por Jorge de Almeida e Wolfgang Bader. São Paulo: Cosac Naify e Instituto Goethe, 2009.

${ }^{22}$ Sigo aqui o excelente artigo de Diego Sanchez-Meca, Généalogie et critique de La philologie aux sources de choses humaines, trop humaines. In : Nietzsche, Philosophie de l'esprit libre. Paris : Rue d'Ulm, 2004. Agradeço a Ernani Chaves pela indicação.

${ }^{23}$ Ver, em particular, NIETZSCHE, F. Über die Zukunft unserer Bildungsanstalten, Kritische Studienausgabe (KSA), vol. I, editado por G. Colli e M. Montinari. München e Berlin: DTV, de Gruyter, 1988. A respeito do entusiasmo da Jugendbewvegung por Nietzsche, ver CHAVES, Ernani. Considerações 
a essa estratégia de manutenção do poder. Enfim, a resistência do corpo docente tradicional a uma concepção não só nova da tragédia grega, mas que também ressalta sua irremediável historicidade, tampouco é neutra: explicitar como a tragédia pode nascer, florescer e morrer num contexto histórico muito preciso, definitivamente encerrado, que nenhuma boa vontade clássica saberia ressuscitar, esse trabalho de explicitação ameaça a corporação dos professores de filologia, porque implica que eles não são os herdeiros de valores eternos, mas os representantes efêmeros de uma configuração temporal também determinada, igualmente entregue ao desaparecimento - a universidade alemã do Século XIX: "Se compreendermos a cultura grega em sua totalidade, percebemos, então, que passou. Por isso, o filólogo é o grande cético de nossa cultura e de nossa educação: eis aí sua missão”, escreve Nietzsche ${ }^{24}$.

Essa concepção radicalmente histórica e radicalmente crítica é evocada por Nietzsche, no fim do prefácio da Segunda Consideração Intempestiva: da Utilidade e da Desvantagem da História para a Vida, o que não deixa de provocar estranheza no leitor; como esse texto é uma das primeiras críticas da historiografia do historicismo, poder-se-ia pensar que Nietzsche se apresenta como um teórico ou um filósofo da história, mas é a partir da filologia como ciência crítica que ele se situa. Cito brevemente as últimas frases, tão conhecidas, da introdução: "[...] Pois eu não saberia qual sentido a filologia clássica poderia em nosso tempo ter afora aquele de agir sobre ele de maneira intempestiva (unzeitgemäss), isto é, agir contra o tempo, portanto sobre o tempo e, esperemos, em proveito de um tempo por vir." 25

É essa Unzeitgemässheit, literalmente, essa não conformidade ao tempo, que serve de fermento filológico na crítica histórica. Essa não-conformidade é uma declaração de guerra contra as pretensões historicistas de "objetividade", um amálgama de opiniões triviais que confortam as convicções do presente, como define Nietzsche:

extemporâneas acerca das "Teses". In: No limiar do Moderno. Estudos sobre Friedrich Nietzsche e Walter Benjamin. Belém: Paka-Katu, 2003.

${ }^{24}$ Citado por Sanchez-Meca, op. cit. p. 88, nota 3; trata-se do fragmento póstumo de 1875, 3 (76), KSA VIII, p. 38: "Die griechische Cultur vollständig begreifend sehen wir also ein, dass es vorbei ist. So ist der Philologe derg ros se Skeptike rin unseren Zuständen der Bildung und Erziebung: das ist seine Mission."

${ }^{25}$ NIETZSCHE, F. Zweite Unzeitgemässe Batrachtung. Vom Nutzen und Nachteil der Geschichte für das Leben, KSA, I, p. 247: “.... denn ich wüsste nicht, was die classische Philologie in unserer Zeit für einen Sinn bätte, wenn nicht den, in ibr unzeitgemäss - das beisst gegen die Zeit und dadurch auf die Zeit und hoffentlich zu Gunsten einer kommenden Zeit-zu wirken.” 
Esses historiadores ingênuos chamam de objetividade ao modo de apreciar os atos e as idéias do passado de acordo com as opiniões correntes do momento; aqui, eles encontram o cânon de todas as verdades; seu trabalho é ajustar o passado às trivialidades do presente. $^{26}$

Há, por assim dizer, um "anacronismo" produtivo na preocupação filológica pela singularidade histórica, anacronismo que não é a marca idiossincrática de uma erudição inútil, mas sim o indício do distanciamento histórico que proíbe uma leitura imediata do passado a partir do presente, porém, que permite, às vezes, lançar uma nova luz, nascida do estranhamento, tanto sobre o passado quanto sobre o presente ${ }^{27}$. Não se trata nem para Nietzsche nem para Benjamin de reclamar privilégios para tranquilos cientistas eruditos, mas, ao contrário, de liberar a pesquisa filológica de sua gaiola empoeirada e de torná-la um instrumento de diferenciação temporal, portanto, um instrumento crítico de análise histórica - do passado e, igualmente, do presente.

Nesse contexto, ganha todo seu peso a afirmação de Nietzsche colocada em epígrafe da tese XII, ainda mais quando se leva em conta que as "Teses" foram escritas em 1940, num esforço teórico tenso de luta contra o nazismo vitorioso, que se apropriou do pensamento de Nietzsche, aproveitando o espólio de sua irmã (nazista), Elizabeth Förster-Nietzsche. Deixo aqui de lado a questão muito controvertida dos possíveis momentos conceituais e das possíveis figuras que podem ou não encorajar, na obra do filósofo, tal apropriação vergonhosa. Importa ressaltar que Nietzsche é por assim dizer "in-citável”, nesse momento crucial da Segunda Guerra, apesar de ter sido um autor de primeira importância para escritores e filósofos inimigos do nazismo e por ele exilados, como Benjamin, Adorno ou Horkheimer.

A epígrafe, oriunda da Segunda Consideração Intempestiva, é a seguinte: "Precisamos da história, mas precisamos dela de outra maneira que o mimado

\footnotetext{
${ }^{26}$ NIETZSCHE, F. Idem, p. 289: “Jene naiven Historiker nennen 'Objektivität' das Messen vergangener Meinungen und Thaten an den Allerwelts-Meinungen des Augenblicks: bier finden sie den Kanon aller Wabrheiten; ibre Arbeit ist, die Vergangenheit der zeitgemässen Tivialitäten anzupassen.” Tradução de Ernani Chaves, a quem devo a lembrança dessa citação (op. cit., p. 56).

${ }^{27}$ Sobre o anacronismo como fator de revelação e de legibilidade histórica, ver DIDI-HUBERMANN, Georges. L'anachronisme fabrique l'histoire: sur l'actualité de Carl Einstein, Revue Etudes Germaniques, janeiro/março de 1998.
} 
caminhante ocioso no jardim do saber." ${ }^{28}$ Chama atenção, nessas palavras, a imagem do "caminhante ocioso", uma prefiguração nietzschiana do flâneur benjaminiano. Os eruditos cientistas do historicismo e os "caminhantes ociosos" (Müssiggänger) que passeiam nas "passagens" parisienses (ou que erram nos shopping centers contemporâneos) são figuras do mesmo individualismo de consumo e vítimas de mecanismos de identificação parecidos. Uns se identificam ao passado, à "massa dos fatos", ressalta Benjamin, na tese XVII; outros à mercadoria, a essa "monstruosa coleção de mercadorias" (Ungeheuere Warensammlung) da qual fala Marx no início do Capital. À vontade no labirinto das vitrines ou das civilizações passadas, historiadores e flaneurs podem assim passear durante sua vida inteira, à procura de algumas descobertas interessantes, ditas científicas, ou de boas compras, ditas "ocasiões". Flânerie científica e flânerie de shopping têm em comum essa atitude de profunda identificação com o valor de troca das mercadorias ou dos assim chamados "bens culturais", esses Kulturgïter denunciados como valores fetiches da cultura por Benjamin.

É evidente que nem Benjamin nem Nietzsche defendem a austeridade do trabalho capitalista contra as alegrias do ócio e do passeio! Ambos foram, pelo contrário, "andarilhos" convictos - nenhum um acadêmico sério exemplar. Mas ambos defendem uma relação crítica, sem falso respeito e com uma atenção tenaz, simultaneamente terna e irreverente, como a de Benjamin em relação a Goethe, ao passado e, particularmente, à transmissão do passado. No caso de Benjamin, essa reflexão sobre a transmissão (Überlieferung) se torna essencial nos últimos escritos mais "materialistas" (o adjetivo é dele) em oposição a uma concepção da tradição (Tradition) como uma continuidade canônica. Benjamin tenta se distanciar, novamente, de duas concepções opostas de tradição cultural: tanto aquela que subjaz à historiografia "burguesa" do historicismo ${ }^{29}$ quanto a que constrói uma narrativa materialista épica. Ambas esquecem que o processo de transmissão faz parte integrante da "tradição", que esta deve ser consequentemente desconstruída e interrogada, para permitir não o encontro com "a imagem eterna do passado', mas sim com a fulguração efêmera da "imagem histórica autêntica que lampeja veloz" (tese VII), porque sempre oriunda de um encontro entre dois tempos específicos

\footnotetext{
28 "Wir brauchen Historie, aber wir brauchen sie anders, als sie der verwöhnte Müssiggänger im Gartendes Wissens braucht." (NIETZSCHE, op. cit. p. 247).

${ }^{29}$ Podemos observar aqui, em compensação, que Benjamin partilha com o historicismo do cuidado pelo detalhe, em oposição a uma historiografia de cunho hegeliano, que desconsidera páginas inteiras da "história universal".
} 
e únicos, o presente no "instante do perigo" e um momento reencontrado, antes esquecido ou negligenciado do passado. ${ }^{30}$

Em suas anotações ligadas à redação do livro sobre Baudelaire - um livro que só temos em capítulos diversos e em várias versões, "censuradas" ou aceitas por Adorno -, Benjamin retoma a questão da verdade da crítica, em particular agora da crítica materialista. Denuncia claramente o elemento "fetichista" que continua a sustentar uma escrita materialista pouco propensa a questionamentos heurísticos e centrada exclusivamente na história da produção das obras da cultura e na posição de classe de seus autores.

\begin{abstract}
A separação (Scheidung) do verdadeiro e do falso não é para o método materialista o ponto de partida, mas o alvo. [...] O método só diminuiria muito suas chances se tivesse a pretensão de abordar a coisa como ela é 'de verdade'; e ele as aumenta consideravelmente, quando desiste dessa pretensão na sua sequência e assim se dispõe a entender que 'a coisa em si' não existe 'e verdade'31.
\end{abstract}

Ir atrás da "coisa em si" é, de fato, atraente. Ela se oferece, no caso de um Baudelaire, copiosamente. As fontes fluem a bel prazer e ali onde se reúnem na corrente da tradição (Überlieferung) abrem-se colinas já traçadas entre as quais ela transcorre até onde a vista alcançar. O materialismo histórico não se perde na contemplação desse espetáculo. Ele não procura pelas imagens das nuvens nessa corrente. Porém, ainda menos se vira para trás para beber "na fonte", na "coisa em si", atrás das costas dos homens. De quem são os moinhos que essa corrente alimenta? Quem a represa? - assim pergunta o materialismo histórico, e ele transforma a imagem da paisagem, ao nomear as forças que nela estiveram em ação.

Parece ser um procedimento complicado; e o é, de fato. Será que não há um mais imediato? Que fosse ao mesmo tempo um mais decidido. O que fala contra a tentativa de simplesmente confrontar o poeta Baudelaire com a sociedade de hoje e de responder à pergunta, na base de sua obra, o que ele ainda tem a dizer a seus quadros avançados; bem entendido, sem esquecerse da pergunta, se ele tem de fato algo a lhes dizer. O que fala contra isso

\footnotetext{
${ }^{30}$ Esse modelo historiográfico tem sua origem explícita em Proust, como o afirma Benjamin. Não é lugar aqui de apontar para suas riquezas e dificuldades, das quais, aliás, Benjamin é consciente. Remeto ao verbete (de minha autoria) sobre as "teses", no já citado Benjamin-Handbuch.

${ }^{31}$ BENJAMIN, Walter. Teses "Sobre o conceito de história”. Tradução de J. M. Gagnebin e Marcos L. Müller. In: LÖWY, Michael. Walter Benjamin: Aviso de incêndio. Uma leitura das teses "Sobre o conceito de história". São Paulo: Boitempo, 2005, p. 65.
} 
é [que] fomos instruídos justamente pela sociedade burguesa na leitura de Baudelaire, durante uma aprendizagem histórica. Essa aprendizagem nunca pode ser ignorada. Uma leitura crítica de Baudelaire e uma revisão crítica dessa aprendizagem são muito mais uma e mesma coisa. Pois é uma ilusão do marxismo vulgar pensar poder determinar a função social, seja de um produto material, seja de um espiritual, fazendo abstração das circunstâncias e dos portadores de sua transmissão (Überlieferung). "Quando o conceito de cultura é considerado como um conjunto de formações que são independentes, não do processo de produção no qual vieram à luz, mas sim daquele, no qual elas continuam a durar, então esse conceito carrega... um traço fetichista" ${ }^{\prime 32}$. Na verdade, "[...] a transmissão (Überlieferung) da poesia baudelairiana ainda é muito curta. Mas já comporta incisões (Einkerbungen) históricas pelas quais a consideração crítica deve se interessar." ${ }^{33}$

Ao ler juntos esse fragmento metodológico e o primeiro parágrafo do ensaio sobre As Afinidades Eletivas, várias diferenças podem ser constatadas. A maior talvez seja a mudança do paradigma predominantemente metafísico e filológico para uma reflexão crítica e hermenêutica, no sentido amplo desta palavra, a respeito do processo de transmissão descrito como um palco de cortes, de usos, de desvios, enfim, de lutas. No entanto, continua clara uma convicção, a saber, que a tarefa crítica é de buscar por um "teor de verdade" que se diz historicamente na obra. Abdicar da concepção "idealista" de uma verdade eterna, afirmar que a verdade é histórica não significa, portanto, cair num relativismo preguiçoso, que se disfarça de tolerante e no qual a rigor não há mais verdade, mas só opiniões. Tampouco significa naturalizar um processo histórico como se fosse um desenvolvimento parecido à corrente de um rio ou ao desabrochar do gênio (em Goethe). Nos dois textos, Benjamin afirma um conceito ao mesmo tempo enfático e totalmente histórico de verdade, que orienta a busca do crítico, quando ele visa não só a uma renovação da imagem do passado, mas também a uma transformação da apreensão do presente. Verdade histórica e crítica do presente coincidem.

\footnotetext{
${ }^{32}$ Autocitação. Benjamin retoma aqui as reflexões desenvolvidas no ensaio Eduard Fucbs. Der Sammler und Historiker, GS II-2, p. 465 e seguintes.

${ }^{33}$ Gesammelte Schriften I-3, p. 1160/1161. Tradução minha.
} 
GAGNEBIN, Jeanne Marie. Comentário filológico e crítica materialista. Trans/Form/Ação, (Marília); v.34, p.137-154, 2011, Edição Especial 2.

RÉSUMÉ: Partant de l'essai (1922) de Walter Benjamin sur les Affinités électives de Goethe, cet article essaie de montrer que Benjamin, depuis cet essai de jeunesse et jusqu'à son dernier texte, les thèses "Sur le concept d'histoire" (1940), défend une conception de philologie critique, qui sache rendre evidente, dans le détail matériel, la distance historique qui separe l'oeuvre, dans sa concretude historique, du moment historique de l'interprète ou de l'historien. Seule, la reconnaissance de cette prise de distance, permet de ne pas tomber dans les pièges de l'Einfüblung (identification affective, empathie) herméneutique et rend possible l'élaboration d'une prise de position historique et critique.

CONCEPTS CLEF: Walter Benjamin. Critique. Philologie. Distance historique.

Campinas, março de 2011. 